\title{
From lean to green management
}

\author{
Elena Ganebnykh ${ }^{1, *}$, Anna Fedyaeva $^{1}$, Yulia Igoshina $^{1}$ and Andrey Ivashchenko ${ }^{2}$ \\ ${ }^{1}$ Vyatka State University, 610000, Moskovskaya str., 36, Kirov, Russia \\ ${ }^{2}$ Moscow State University of Civil Engineering, 129337, 26, Yaroslavskoe Shosse, Moscow, Russia
}

\begin{abstract}
The article is devoted to testing the hypothesis of Melnyk et al. that companies implementing principles of Lean Management System are more environmentally friendly than those that do not implement them. Melnyk tested his hypothesis in North American companies, where Lean Management System and Green Management System are introduced almost simultaneously. Russian production practice is significantly different from the American one, and Lean manufacturing is significantly ahead of Environmental management principles. To test the hypothesis, a formed sample of a number of Russian manufacturing companies was rather small, but the results were fully confirmed.
\end{abstract}

\section{Introduction}

The industrial period of society development was based on three pillars: cost, time and quality. The transition to post-industrialism symbolizes avoiding manual labour in the production of material goods through total robotization and automation of production processes. Lean Manufacturing is focused on "cleaning " all production processes from non-productive operations, the so-called wastes. In fact, Lean becomes an intermediate between manual labor and automation [1]. Once the process is optimized to the "value only" state, all its operations can be easily automated.

However, post-industrialism is not only production of intangible goods and consolidation of information flows. One of the most important principles of modern development of both the whole society and individual production systems is their sustainable development. Sustainable development is the organizing principle for meeting human development goals while at the same time sustaining the ability of natural systems to provide the natural resources and ecosystem services upon which the economy and society depend. How does Sustainable Manufacturing (SM) fit into the concept of sustainable development of society? In 2017, Moldavska and Welo [2] conducted a study that analyzed 189 scientific articles and identified 89 original definitions of sustainable manufacturing. The authors pointed out the following problems: a wide deviation from the core understanding of the SM concept, inconsistency in the understanding of issues associated with SM concept, and a mix of performance-related features and sustainabilityoriented instruments in the definitions of the SM concept.

\footnotetext{
*Corresponding author: ganebnykh@mail.ru
} 
It is obvious that at present there is no uniform understanding of the concept of SM, but most authors distinguish its component of TPL (Triple bottom line) - social, environmental (or ecological) and financial frameworks. At the same time, in a competitive market, a clear trend is the struggle for cost reduction. Lean Manufacturing is a method of customeroriented organization of production processes aimed at reducing waste without compromising performance. The ultimate goal of Lean manufacturing is to reduce production costs and increase product quality.

"Green" technologies are traditionally believed to be expensive, while lean manufacturing is aimed at streamlining and reducing the cost component of the production of goods and services. At first glance, there is an obvious conflict of interest. However, recent studies indicate a synergistic effect between lean and green technologies. Bergmiller and McCright [4], comparing Green System Model and Lean System Model, show the relationship of tools and results of both systems and form a unified Advanced Green System Model (Fig.1).

\begin{tabular}{|c|}
\hline Lean/Green \\
Management \\
System \\
Leadership \\
Empowerment \\
Environmental \\
Management \\
System \\
Years \\
ISO14001 \\
Certified \\
\hline
\end{tabular}
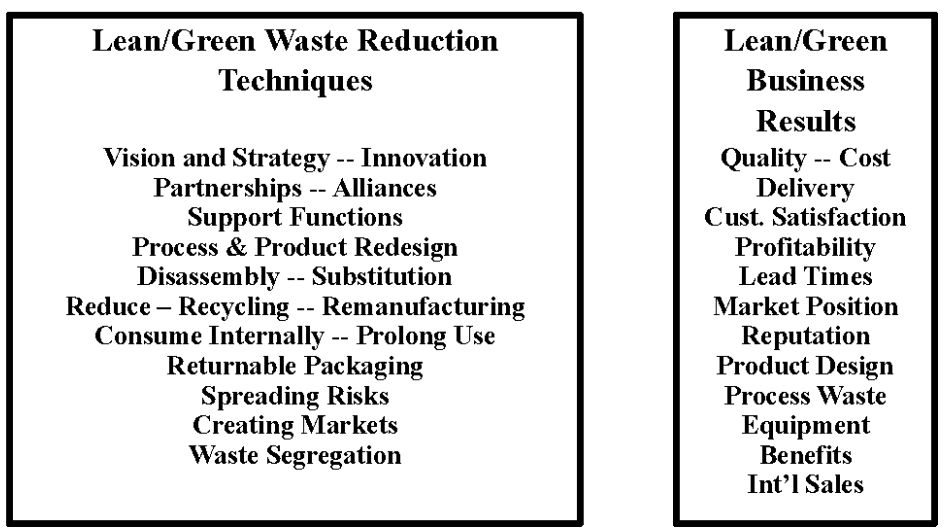

Fig. 1. Advanced Green System Model (by Bergmiller and McCright).

Everyone understands clearly the need for Russian industry to develop on a sustainable path. While interest in Lean technologies is increasing, penetrating deeper not only into manufacturing enterprises, but also into the service sector, and even the public sector, there remains a strong prejudice about the high cost of introducing green technologies. However, according to studies by Melnyk et al. [4], Lean manufacturers are significantly greener than the general population of manufacturers. It is based on the fact that Lean Production Systems are founded on the idea of building organizational efficiency by obtaining as much or more production from consuming less resources (primarily materials and labor) [5]. A reduction in the use of resources is a saving green technology. Thus, pursuing materialistic goals, in fact, the manufacturer converts the business into a more eco-friendly.

Melnyk et al. tested their hypothesis on a large community of 1100 North American companies. Later, Bergmiller and McCright expanded the list of the analyzed factors by including more Lean indicators in the questionnaires, but they also tested their model on North American companies.

The history of Lean Management in North America is much longer. Manufacturers have a deeper understanding of the effectiveness of this company management method. Russian practice of Lean implementation is hardly over 15 years, but in recent years the interest of Russian companies in managing with Lean technologies has become more noticeable. The aim of our study is to test Melnyk et al. research technique on Russian companies implementing Lean technologies. The results will allow Russian manufacturers to take a fresh look at building their own Green Management Systems and may serve as a kind of incentive for the early introduction of Lean-technologies at their enterprises. 


\section{Methods}

Melnyk et al. methodology involves conducting a survey to gather information from respondents about their attitudes to environmental business activities and voluntary environmental programs such as ISO 14001. For our research, we adopted a survey form developed by them. In the course of their study, Melnyk et al. also identified the factors influencing respondents' attitude and understanding of productivity and efficiency of their plant's environmental management system were also identified. We included these factors in our questionnaires. Our questionnaires were also supplemented by a list of Lean factors developed by Bergmiller and McCright during their research [3].

In general, the survey consists of 6 groups of questions:

1. Personal information about the respondent, his / her position and degree of involvement in various production initiatives,

2. Description of production, including manufactured goods and initiated programs,

3. Quality management system at the enterprise and its position on the market,

4. Respondent's assessment of various positions related to standard 14001

(environmental management system),

5. Collection of information on current environmental indicators and respondent's vision of the ways to improve them,

6. Collection of information about Lean-management of the enterprise.

The information obtained in the course of the research is a subjective opinion of the respondents. The questionnaires were sent by e-mail to the producers of the Kirov region through the Ministry of industrial policy of the Kirov region, so the research is a case study and has a very limited sample. Among the industrial enterprises we selected those industries where the issues of environmentally friendly production are quite acute. In total, 35 requests were sent to industrial enterprises of the following industries: 9 requests to chemical enterprises, 14 enterprises of machine-building industry, 2 metallurgical production, 10 enterprises of light industry. The inquiries were directed to the General Directors of the companies, but they were not always the respondents. In 14 cases out of 33, responses were received from Deputy General Directors for production, quality and also from Executive Directors. The information obtained was presented as follows (table 1).

Table 1. Dependent variables: summary information.

\begin{tabular}{|c|c|}
\hline Number & Variable \\
\hline \multicolumn{2}{|c|}{ 1. Environmental activities within your plant have } \\
\hline 1.1 & Significantly reduced overall costs \\
\hline 1.2 & Significantly reduced lead times \\
\hline 1.3 & Significantly improved product quality \\
\hline 1.4 & Significantly improved its position in the marketplace \\
\hline 1.5 & Helped enhance the reputation of your company \\
\hline 1.6 & Helped your company design/develop better products \\
\hline 1.7 & Significantly reduced waste within the production process \\
\hline 1.8 & Significantly reduced waste within the equipment selection process \\
\hline 1.9 & Had benefits that have definitely outweighed any costs incurred \\
\hline 1.10 & Improved its chances of successfully selling its products in international markets \\
\hline \multicolumn{2}{|c|}{2. To what extent are the following options considered within your company } \\
\hline 2.1 & Product redesign \\
\hline 2.2 & Process redesign \\
\hline 2.3 & Disassembly \\
\hline 2.4 & Substitution \\
\hline
\end{tabular}




\begin{tabular}{|c|c|}
\hline 2.5 & Reduce \\
\hline 2.6 & Recycle \\
\hline 2.7 & Rebuild \\
\hline 2.8 & Remanufacture \\
\hline 2.9 & Consume internally \\
\hline 2.10 & Prolong use \\
\hline 2.11 & Returnable packaging \\
\hline 2.12 & Spread risks \\
\hline 2.13 & Create a market for waste products \\
\hline 2.14 & Waste segregation \\
\hline 2.15 & Relocation \\
\hline 2.16 & Alliances \\
\hline
\end{tabular}

\section{Results}

The questionnaires were sent during June 2018, and the responses were compiled in September 2018. According to Alreck and Settle [6], responses to mail requests usually do not exceed $30 \%$. However, in our case, the administrative resource was used, due to which the number of responses was $94 \%$. In general, the quality of filling in questionnaires is estimated as high (almost all questions were answered, there were no omissions), some points indicated in the questionnaires inexplicitly were clarified over the phone. In this regard, the results of the survey have a high degree of reliability.

To verify the reliability of the data obtained, the Kronbach's alpha coefficient (formula 1) was used.

$$
\alpha_{s t}=\frac{N * \bar{r}}{1+(N-1) * \bar{r}}
$$

where $\mathrm{N}$ is the number of components studied, and determines the average correlation coefficient between the components [7]. Kronbach's alpha coefficient was 0.8 , which is a good value on the interpretation scale and indicates the acceptable reliability of the entire data set. The assessment of correlations by using software statistical SPSS has shown the presence of high values in blocks of Lean Management System and Green Management System. It is interesting that the correlations within the blocks coincide structurally, which confirms the theory of Bergmiller and McCright on the homogeneity of Lean and Green Systems. In general, both indicators together indicate that, despite the small sample size, it is statistically significant.

Student's t-test was used to evaluate the obtained data [8]. For each variable, the total number of responses $(\mathrm{N})$ was specified, the mean value of the variable (Mean) and standard deviation (SD) was calculated.

For the purposes of our study, we used a two-sample t-test for independent samples (formula 2).

$$
t=\frac{\left|X_{1}-X_{2}\right|}{\sqrt{\frac{\sigma_{1}^{2}}{n_{1}}+\frac{\sigma_{2}^{2}}{n_{2}}}}
$$

where $X$ is the mean of the variable, $\sigma$ is the standard deviation, and $n$ is the number of respondents.

The results are shown in table 2. 
Table 2. T-test results.

\begin{tabular}{|c|c|c|c|c|c|c|c|c|}
\hline \multirow{2}{*}{ \# } & \multirow{2}{*}{ Variable } & \multicolumn{3}{|c|}{ Melnyk et al. } & \multicolumn{3}{|c|}{ Kirov } & \multirow[t]{2}{*}{$\mathrm{t}$} \\
\hline & & $\mathrm{N}$ & Mean & SD & $\mathrm{N}$ & Mean & $\mathrm{SD}$ & \\
\hline \multicolumn{9}{|c|}{ 1. Environmental activities within your plant have } \\
\hline 1.1 & $\begin{array}{l}\text { Significantly reduced } \\
\text { overall costs }\end{array}$ & 1142 & 3.35 & 2.57 & 34 & 2.20 & 5.60 & 1.19 \\
\hline 1.2 & $\begin{array}{l}\text { Significantly reduced } \\
\text { lead times }\end{array}$ & 1143 & 2.71 & 2.28 & 34 & 1.90 & 4.18 & 1.13 \\
\hline 1.3 & $\begin{array}{l}\text { Significantly improved } \\
\text { product quality }\end{array}$ & 1144 & 3.24 & 2.53 & 35 & 4.10 & 4.98 & 1.20 \\
\hline 1.4 & $\begin{array}{l}\text { Significantly improved } \\
\text { its position in the } \\
\text { marketplace }\end{array}$ & 1140 & 3.48 & 2.70 & 35 & 3.50 & 5.22 & 0.02 \\
\hline 1.5 & $\begin{array}{l}\text { Helped enhance the } \\
\text { reputation of your } \\
\text { company }\end{array}$ & 1144 & 4.85 & 3.09 & 35 & 5.10 & 5.94 & 0.25 \\
\hline 1.6 & $\begin{array}{l}\text { Helped your company } \\
\text { design/develop better } \\
\text { products }\end{array}$ & 1144 & 3.60 & 2.77 & 34 & 3.50 & 4.31 & 0.13 \\
\hline 1.7 & $\begin{array}{l}\text { Significantly reduced } \\
\text { waste within the } \\
\text { production process }\end{array}$ & 1144 & 4.73 & 2.99 & 35 & 3.70 & 5.07 & 1.39 \\
\hline 1.8 & $\begin{array}{l}\text { Significantly reduced } \\
\text { waste within the } \\
\text { equipment selection } \\
\text { process }\end{array}$ & 1133 & 4.02 & 2.79 & 35 & 6.10 & 8.66 & 0.97 \\
\hline 1.9 & $\begin{array}{l}\text { Had benefits that have } \\
\text { definitely outweighed } \\
\text { any costs incurred }\end{array}$ & 1138 & 4.21 & 2.83 & 33 & 4.00 & 4.78 & 0.30 \\
\hline 1.10 & $\begin{array}{l}\text { Improved its chances of } \\
\text { successfully selling its } \\
\text { products in international } \\
\text { markets }\end{array}$ & 1133 & 3.73 & 2.89 & 34 & 3.90 & 4.96 & 0.23 \\
\hline \multicolumn{9}{|c|}{ 2. To what extent are the following options considered within your company } \\
\hline 2.1 & Product redesign & 1163 & 4.99 & 3.07 & 33 & 3.90 & 4.85 & 1.28 \\
\hline 2.2 & Process redesign & 1166 & 5.95 & 2.91 & 32 & 3.70 & 5.15 & 2.69 \\
\hline 2.3 & Disassembly & 1155 & 4.03 & 3.02 & 32 & 3.80 & 4.87 & 0.31 \\
\hline 2.4 & Substitution & 1163 & 6.02 & 3.05 & 34 & 5.80 & 7.14 & 0.15 \\
\hline 2.5 & Reduce & 1160 & 5.82 & 3.03 & 35 & 5.60 & 2.78 & 0.96 \\
\hline 2.6 & Recycle & 1165 & 5.48 & 3.19 & 35 & 6.20 & 7.15 & 0.49 \\
\hline 2.7 & Rebuild & 1153 & 4.80 & 3.21 & 34 & 3.20 & 5.26 & 1.94 \\
\hline 2.8 & Remanufacture & 1148 & 4.16 & 3.12 & 35 & 2.90 & 8.69 & 0.58 \\
\hline 2.9 & Consume internally & 1163 & 3.66 & 2.99 & 35 & 2.80 & 5.38 & 1.03 \\
\hline
\end{tabular}




\begin{tabular}{|l|l|r|r|r|r|r|r|r|}
\hline 2.10 & Prolong use & 1154 & 5.01 & 3.98 & 35 & 6.40 & 9.23 & 0.57 \\
\hline 2.11 & Returnable packaging & 1162 & 5.81 & 3.23 & 34 & 4.60 & 5.44 & 1.38 \\
\hline 2.12 & Spread risks & 1153 & 4.44 & 2.89 & 34 & 4.40 & 7.63 & 0.02 \\
\hline 2.13 & $\begin{array}{l}\text { Create a market for } \\
\text { waste products }\end{array}$ & 1156 & 4.24 & 3.07 & 35 & 5.20 & 6.38 & 0.82 \\
\hline 2.14 & Waste segregation & 1161 & 5.83 & 3.05 & 34 & 5.30 & 6.89 & 0.38 \\
\hline 2.15 & Relocation & 1153 & 3.30 & 2.85 & 35 & 2.80 & 4.33 & 0.92 \\
\hline 2.16 & Alliances & 1154 & 4.96 & 3.05 & 35 & 3.10 & 7.69 & 1.05 \\
\hline
\end{tabular}

According to the evaluation of the Student's t-test data, all indicators except 2.2. Process redesign has a high level of significance, which means that there are no differences between the groups according to these indicators. The only difference is the value at the boundary between medium and low. This does not detract in general from the fact that the results of the study almost completely coincide with the results of Melnyk et.al.

\section{Discussion}

Russian enterprises are currently in the intermediate stage of implementation of both Lean Management System and Green Management System.

The regulatory framework for the construction and development of the Green Management System is the international standard ISO 14000 series. Its domestic analogue, fully authentic to the original, ISO 14001-2016 (GOST R), was approved in 2016 and came into force since 01.03.2017 [9]. In fact, a few enterprises practice a complete list of norms of this standard. The situation with Lean Management System is somewhat different. The ISO 9000 standards was introduced in Russia in 2000, however, companies began to implement the principles of lean manufacturing seriously much later. Since the early 2000 s, only giant companies have been interested in this concept. However, at present, the principles of lean management penetrate deeper into the enterprises of not only large but also medium-sized businesses, and even public institutions.

Conscious implementation of environmental management system standards usually occurs at a later stage of the company's life cycle. This usually coincides with the stage of maturity [10] of the company together with the awareness of the social responsibility of the business. In a stable economic system, the introduction of lean principles is also caused by the problems of the maturity stage: the growth of non-production processes in the company and their costs. However, in Russian economy of shocks, external factors often push enterprises to take steps, usually uncharacteristic of their stages of development. So the crisis that began in 2014 forced producers to seek internal reserves to reduce costs. In this light, it becomes clear high interest to lean manufacturing. Thus, in Russian organizations build Lean Management System much faster than Green Management System in the organization.

\section{Conclusion}

Russian economy is characterized by a lack of long periods of stability. Recurrent crises are forcing enterprises to go to unusual under normal conditions steps. So at present the companies are concerned with the search for internal reserves to reduce costs. At the same 
time, the environmental component of production is on one of the last places and is observed at a minimum level, which is provided by a rather weak environmental legislation.

The analysis carried out in the research showed that enterprises implementing Lean Management System, regardless of their initial intentions, are significantly more environmentally friendly than those who do not implement these principles. In fact, the first researchers to prove this hypothesis were Melnyk, S.A., Sroufe, R., and Calantone, R. J. [4], checking it on the North American companies.

As in standard conditions of the competitive market enterprises introduce Lean Management System and Green Management System almost simultaneously, the mutual correlation of the factors of both systems is clear. However, in Russian practice, a forced measure is the earlier implementation of Lean Management System than Green Management System. In this regard, we conducted a study on the method of Melnyk et.al. on the basis of a small sample of Russian industrial companies of the Kirov region. The results fully confirmed the version of Melnyk et.al. The introduction of lean management principles entails the growth of environmental production.

\section{References}

1. E. Ganebnykh, I. Altsybeeva, E. Gurova, SHS Web of Conferences 35, 01029 (2017)

2. A. Moldavska, T. Welo, Journal of Cleaner Production 166, 744-755 (2017)

3. G.G. Bergmiller, P.R. McCright, Proceedings of the 2009 Industrial Engineering Research Conference 1, 17-28 (2009)

4. S.A. Melnyk, R. Sroufe, , R.J. Calantone, Journal of Operations Management 21, 329351 (2003)

5. J. Liker, The Toyota Way: 14 Management Principles from the World's Greatest Manufacturer (McGraw-Hill, New York, 2004)

6. P.L. Alreck, R.B. Settle, The Survey Research Handbook (Homewood, Irwin, 1995)

7. L.J. Cronbach, Psychometrika 16, 297-334 (1951)

8. D.W. Zimmerman, Journal of Educational and Behavioral Statistics 22(3), 349-360 (1997)

9. V.A. Pukhkal, A.B. Mottaeva, Magazine of Civil Engineering 81(5), 203-212 (2018) doi: 10.18720/MCE.81.20

10. I. Adizes, Organizational Dynamics 8(1), 3-25 (1979) 